\title{
WPŁYW ZAWODNOŚCI DIAGNOSTYCZNEJ WŁADZ MONETARNYCH NA SKUTECZNOŚĆ ANTYCYKLICZNEJ POLITYKI STABILIZACYJNEJ
}

\section{WSTĘP}

Zagwarantowanie niskiej i stabilnej inflacji, przy jednoczesnej możliwie wysokiej średnio- i długookresowej dynamice produktu krajowego stanowi podstawowe zadanie polityki gospodarczej. Zdolność do realizacji tak sformułowanego celu jest obecnie uważana za kluczowy wkład władz monetarnych w podniesienie dobrobytu społecznego obywateli. Ostatnie lata były okresem rosnącej wiary w możliwości decydentów monetarnych stosunkowo łatwego osiągania tak sformułowanego celu. Sprzyjały temu ogromne postępy w zakresie samej teorii polityki monetarnej, jak również niespotykany wcześniej postęp w odniesieniu do ekonometrycznych narzędzi diagnozowania bieżącego stanu gospodarki oraz jego prognozowania. Jednakże bieżący globalny kryzys gospodarczy oraz poważne błędy polityki pieniężnej Rezerwy Federalnej - jednego z najważniejszych banków centralnych świata - z lat 2001-2006, które w sposób zasadniczy przyczyniły się do powstania bąbla spekulacyjnego prowadzącego do tego kryzysu ${ }^{1}$, przypominają o bardzo wysokim skomplikowaniu zadania, wobec jakiego stoją wszystkie banki centralne świata.

Celem niniejszego opracowania jest ukazanie czynników związanych z zagrożeniami nieefektywnością informacyjną decydentów monetarnych, które mogą utrudniać prowadzenie skutecznej antycyklicznej polityki pieniężnej, a które czę-

\footnotetext{
${ }^{1}$ Wpływ ekspansywnej polityki monetarnej Rezerwy Federalnej z lat 2001-2006 na powstanie kryzysu jest szczegółowo omawiany w pracach: A. P. Balcerzak, Państwo w realiach „nowej gospodarki". Podstawy efektywnejpolityki gospodarczej w XXI wieku, Wydawnictwo Adam Marszałek, Torun 2009, s. 314-339; A. J. Schwartz, Origins of the Financial Crisis of 2008, „Cato Journal” 2009, vol. 29, no. 1, s. 19-23; L. H. White, Federal Reserve Policy and the Housing Bubble, „Cato Journal" 2009, vol. 29, no. 1, s. 115-125.
} 
sto wydają się bagatelizowane. Ma to podstawy w coraz powszechniejszym zaufaniu ekonomistów do ich rosnących zdolności do efektywnego przetwarzania informacji.

W opracowaniu nieefektywność informacyjna oraz, zamiennie, zawodność diagnostyczna decydentów monetarnych są rozumiane jako brak możliwości precyzyjnego określenia przez decydentów monetarnych relacji bieżącej aktywności gospodarczej do produktu potencjalnego. Efektywność antycykliczna polityki monetarnej oraz, zamiennie, efektywność monetarnej polityki stabilizacyjnej są rozumiane jako zdolność władz monetarnych do zamknięcia luki popytowej umożliwiającą stabilizację produktu na możliwie wysokim poziomie bez groźby rozbudzenia inflacji.

\section{WSPÓŁCZESNE STANDARDY POLITYKI MONETARNEJ}

Ostatnie trzydziestolecie było okresem wypracowania oraz dyfuzji tzw. dobrych praktyk w zakresie polityki monetarnej, które przekładały się na długookresowe antyinflacyjne sukcesy większości banków centralnych krajów wysoko rozwiniętych. Frederic Mishkin przytacza dziewięć fundamentalnych zasad współczesnej polityki monetarnej, które są obecnie przedmiotem konsensusu w głównym nurcie ekonomii: 1) w średnim i dłuższym okresie inflacja jest zawsze zjawiskiem monetarnym; 2) stabilność cen jest źródłem ważnych korzyści; 3) nie istnieje długookresowa wymienność między bezrobociem a inflacją; 4) oczekiwania odgrywają kluczową rolę w kształtowaniu procesów inflacyjnych oraz wpływają na mechanizm transmisji impulsów monetarnych; 5) akceptacja dla reguły Taylora, zgodnie z którą działania antyinflacyjne wymagają podnoszenia realnych, a nie tylko nominalnych stóp procentowych; 6) polityka monetarna jest narażona na zjawisko dynamicznej niespójności w czasie; 7) czynnikiem wpływającym na podniesienie efektywności polityki monetarnej jest niezależność banku centralnego; 8) rosnące znaczenie polityki bezpośredniego celu inflacyjnego; 9) kryzysy na rynkach finansowych odgrywają silną rolę w kształtowaniu cyklów koniunkturalnych².

Większość powyższych „naukowych zasad polityki monetarnej” została sformułowana dzięki wysiłkowi ekonomistów, którzy byli zwolennikami ograniczenia antycyklicznej aktywności państwa. Badali oni takie endogeniczne czynniki ograniczające efektowność polityki monetarnej, jak: opóźnienia czasowe w mechanizmach transmisji monetarnej, efekty wypychania, wpływ oczekiwań racjonalnych

\footnotetext{
${ }^{2}$ Zob. F. S. Mishkin, Will Monetary Policy Become More of a Science?, „NBER Working Paper Series” 2007, Working Paper 13 566, October.
} 
bądź adaptacyjnych, konsekwencje oczekiwań inflacyjnych oraz przyczyny nieefektywności dyskrecjonalnych działań władz monetarnych w kontekście zjawiska niespójności w czasie ${ }^{3}$. Jak wynika z przytaczanych powyżej uwag Frederica Mishkina, argumentacja ta została obecnie zaakceptowana przez decydentów monetarnych.

W ostatnich latach szczególnie dużego znaczenia nabrały reguły polityki monetarnej odpowiadające na zmiany inflacji oraz poziomu aktywności gospodarczej, które bazują na relacji bieżącej aktywności gospodarczej do potencjalnego poziomu produktu przy pełnym wykorzystaniu czynników produkcji ${ }^{4}$. Według Johna Taylora, który zaproponował jedną z najpopularniejszych $\mathrm{w}$ ostatnich latach reguł tego typu ${ }^{5}$, jasne reguły stanowią fundament współczesnej bankowości centralnej zarówno w przypadku krajów wyrażających explicite swój bezpośredni cel inflacyjny ${ }^{6}$,jak i przyjmujących go implicite. Reguły pozwalają na wystarczającą elastyczność prowadzącą do stabilizacji produktu bez groźby rozbudzenia inflacji. Jednocześnie gwarantują one zachowanie dyscypliny uniemożliwiającej dyskrecjonalne działania skutkujące niespójnością w czasie ${ }^{7}$. Zgadza się z tym poglądem A.

${ }^{3}$ A. Lipowski, Ekonomiczna zawodnośc państwa - krytyczna analiza ujęcia antyetatystycznego, „Ekonomista” 2002, nr 2, s. 170; A. Wojtyna, Nowoczesne państwo kapitalistyczne a gospodarka. Teoria i praktyka, Państwowe Wydawnictwo Naukowe, Warszawa 1990, s. 55-98.

${ }^{4}$ A. Orphanides, The Quest for Prosperity Without Inflation, "Journal of Monetary Economics" 2003, vol. 50, s. 635.

${ }^{5}$ John Taylor zaproponował opis polityki monetarnej Rezerwy Federalnej z drugiej połowy lat 80 . i początku lat 90 . w oparciu o regułę, gdzie w funkcji reakcji stopy procentowej zostały uwzględnione zarówno odchylenia realnego PKB od jego wartości nominalnej, jak i poziom cen według następującego równania: $r=p+5 y+5(p-2)+2$, gdzie: $r$ oznaczało stopę rezerwy federalnej, $p$ poziom inflacji z poprzednich czterech kwartałów, $y$ odchylenie realnego poziomu PKB od jego wartości nominalnej, a więc $y=100\left(Y-Y^{*}\right) / Y^{*}$; gdzie: $Y$ poziom realnego PKB, $Y^{*}$ trend GDP, co dla lat 1984-1992 wynosiło 2,2\% rocznie. Tak sformułowana reguła polityki monetarnej oznacza, że Rezerwa Federalna podnosiła stopę procentową, jeżeli stopa inflacji przekroczyła cel równy $2 \%$ lub gdy realny PKB znalazł się powyżej potencjalnego PKB. Jeżeli zarówno inflacja, jak i realny PKB były zgodne z celem, wówczas stopa rezerwy federalnej równała się 4\% lub $2 \%$ według wartości realnej. Wykorzystanie stopy inflacji z czterech poprzednich kwartałów po prawej stronie równania wskazywało, że reguła polityki monetarnej bazowała na wartościach realnych z opóźnioną stopą inflacji służącą jako przybliżenie dla inflacji oczekiwanej. 2\% wartość realnej stopy „równowagi” była zbliżona do zakładanej stopy zrównoważonego wzrostu wynoszącego 2,2\%. Powyższa reguła miała takie same zmienne dla odchyleń realnego PKB od trendu, jak i stop inflacji. J. B. Taylor, Discretion Versus Policy Rules in Practice, Carnegie-Rochester Conference Series on Public Policy, 1993, vol. 39, s. 202.

${ }^{6}$ Syntetyczną analizę najważniejszych elementów polityki bezpośredniego celu inflacyjnego banku centralnego można znaleźć w pracy K. Rybińskiego, Globalizacja w trzech odstonach. Offshoring - globalne nierównowagi - polityka pieniężna, Diffin, Warszawa 2007, s. 256-261. Bardzo bogate rozważania w tej materii zawarte są natomiast w książce A. Wojtyny, Szkice o polityce pieniężnej, Polskie Wydawnictwo Ekonomiczne, Warszawa 2004.

${ }^{7}$ Zob. J. B. Taylor, The Robustness and efficiency of monetary policy rules as guidelines for interest rate setting by the European central Bank, „Journal of Monetary Economics” 1999, vol. 43, no. 3, 
Orphanides, według którego współcześnie stosowane reguły polityki pieniężnej, w szczególności te bazujące na regule Taylora, pozwalają na uchwycenie trzech powszechnie uznawanych elementów dobrej polityki gospodarczej: gwarantują silną systematyczną odpowiedź na pojawiające się zjawiska inflacyjne, zapewniają acykliczny element polityki w kontekście wahań koniunkturalnych, rozwiązują problem opóźnień czasowych związanych z mechanizmem transmisji monetarnej dzięki wykorzystywaniu prognoz inflacji oraz poziomu bezrobocia jako wskaźników stanu aktywności gospodarczej ${ }^{8}$. Poza tym według K. Rybińskiego jasne reguły przyczyniają się do wzrostu czytelności i przewidywalności działań banku centralnego dla sektora prywatnego, co jest obecnie traktowane jako ważny element stabilizacji oczekiwań inflacyjnych, a tym samym stabilizacji samej inflacji ${ }^{9}$. W konsekwencji uznaje się, że polityka monetarna uwzględniająca regułę Taylora spełnia lub jest bliska spełnienia kryteriów optymalnej polityki gospodarczej zarówno w przypadku relatywnie skomplikowanych modeli polityki gospodarczej, jak i względnie prostych modeli. Spełnia warunki optymalnej polityki monetarnej dla poszczególnych krajów Europy, a także w znacznej mierze Europejskiego Banku Centralnego ${ }^{10}$, jak również dla Stanów Zjednocznych ${ }^{11}$.

Stosowanie reguł polityki monetarnej może rzeczywiście rozwiązywać tradycyjne, dobrze rozpoznane źródła nieefektywności polityki pieniężnej. Jednak-

s. 655-697. Zgodnie z koncepcją niespójności w czasie dyskrecjonalna polityka gospodarcza, która nie jest związana jasnymi i długookresowymi celami, prowadzi do kontrefektywnych rezultatów gospodarczych. W związku z istnieniem dynamicznych racjonalnych oczekiwań podmiotów gospodarczych, krótkookresowa polityka gospodarcza, która indywidualnie w oderwaniu od oczekiwań wydaje się optymalna w krótkim czasie, staje się nieoptymalna w długim horyzoncie czasowym.

${ }^{8}$ A. Orphanides, Monetary-Policy Rules and the Great Inflation, "American Economic Review" 2002, vol. 92, no. 2, s. 116 .

${ }^{9}$ Pogląd o silnym wpływie efektywności komunikacyjnej między bankiem centralnym a rynkami finansowymi oraz przewidywalności działań tego pierwszego jest jednym $z$ istotnych relatywnie nowych elementów tzw. pryncypiów współczesnej polityki monetarnej. Jeszcze w okresie szczytowego rozwoju nowej ekonomii klasycznej, przypadającym na przełom lat 70. i 80. XX w., przyjmowano, że warunkiem skuteczności polityki pieniężnej jest zdolność banku centralnego do zaskakiwania rynków i zachowania nieprzewidywalności. Kwestie te są także syntetycznie omówione przez Krzysztofa Rybińskiego, zob. K. Rybiński, op. cit., s. 247-254.

${ }^{10}$ John Taylor przedstawił bardzo obszerną bibliografię badań nad efektywnością reguł polityki monetarnej obejmującą estymowane małe lub kalibrowane modele nieuwzględniające racjonalnych oczekiwań, estymowane lub kalibrowane modele $\mathrm{z}$ racjonalnymi oczekiwaniami, modele optymalizacyjne $\mathrm{z}$ reprezentatywnym agentem, duże ekonometryczne modele $\mathrm{z}$ racjonalnymi oczekiwaniami oraz badania obejmujące historyczne oraz międzynarodowe porównania. Zob. J. B. Taylor, The Robustness..., s. 659.

${ }_{11}$ Według Gregory'ego Mankiwa polityka monetarna Stanów Zjednoczonych w latach 90. XX w. może być satysfakcjonująco opisana za pomocą prostej funkcji reakcji uwzględniającej poziom inflacji bazowej i poziom bezrobocia. Zob. N. G. Mankiw, U.S. Monetary Policy During the 1990s, „NBER Working Paper Series” 2001, Working Paper 8471, September. 
że efektywność antycyklicznej polityki monetarnej cały czas uzależniona jest od trzech elementów: a) względnie dobrej oceny aktualnego stanu gospodarki oraz poziomu bieżącego, realnego $\mathrm{PKB}$; b) dobrej oceny normalnej trajektorii gospodarki stanowiącej punkt odniesienia dla monetarnych działań stabilizacyjnych, a więc oceny wysokości potencjalnego PKB; c) efektywnych narzędzi, które pozwalają na zmniejszenie luki inflacyjnej lub recesyjnej luki produktu ${ }^{12}$. Wynika z tego, że warunkiem brzegowym efektywności stabilizacji monetarnej jest bardzo wysoka efektywność informacyjna, konieczna do spełnienia punktów a) i b). Oczywiste jest, że niespełnienie tych dwóch warunków będzie miało bardzo silne negatywne konsekwencje dla efektywności narzędzi wykorzystywanych w polityce stabilizacyjnej. W związku $\mathrm{z}$ tym dalsza analiza będzie się koncentrować na tych dwóch punktach.

Obecnie warunek a) wydaje się relatywnie łatwy do spełnienia ze względu na możliwość wykorzystania porównań historycznych oraz ekonometrycznej ewaluacji stanu bieżącej aktywności gospodarczej. Jednakże w praktyce gospodarczej nawet $\mathrm{w}$ tej kwestii pojawiają się często poważne rozbieżności związane $\mathrm{z}$ tzw. luką rozpoznania (recognition lag), w wyniku której zarówno władze monetarne oraz fiskalne, jak i analitycy rynkowi często dostrzegają zmiany w poziomie aktywności gospodarczej z kilkumiesięcznym opóźnieniem ${ }^{13}$. Oprócz tego na tym etapie kształtowania działań polityki monetarnej pojawia się jeszcze konieczność uwzględnienia prognoz inflacji i bezrobocia, co jest warunkiem ograniczenia wpływu opóźnień mechanizmów transmisji monetarnej i zachowania efektywności reguły Taylora. Już w tym momencie należy oczekiwać pewnego wpływu na efektywność polityki pieniężnej błędów prognoz ${ }^{14}$. Tym samym, uwzględniając prognozy zamiast realnych wyników gospodarki, które nie mogą być znane w chwili podjęcia decyzji o kierunku działań gospodarczych, działania władz monetarnych nieumyślnie mogą odpowiadać na błędy oraz generować dodatkowe elementy zakłócające w polityce monetarnej ${ }^{15}$.

Jednakże jeszcze większe problemy pojawiają się w kontekście spełnienia warunku b). Ekonomiści są zgodni co do istnienia wartości określanej jako potencjalny $\mathrm{PKB}$, który w praktyce często szacowany jest na podstawie popularnych

${ }^{12}$ Federal Reserve Bank of Cleveland, Theory Ahead of Rhetoric: Measurement and the "New Economy”, 2000 Annual Report, s. 10.

${ }^{13}$ Ibidem, s. 9-10. Efektywność banków centralnych w tym zakresie często nie jest znacząco wyższa niż sektora prywatnego mimo dużo wyższych nakładów środków przeznaczanych przez banki centralne na analizę stanu aktywności gospodarczej, czemu powszechnie przypisuje się przewagę informacyjną władz monetarnych nad sektorem prywatnym. K. Rybiński, op. cit., s. 250 .

${ }^{14}$ Problemy te zostaną bardziej szczegółowo omówione w kolejnej części artykułu.

${ }^{15}$ A. Orphanides, Monetary-Policy..., s. 116. 
procedur ekonometrycznych, jak np. filtr Hodricka-Prescotta ${ }^{16}$. Jasne jest także, że możliwe są krótkookresowe odchylenia realnego PKB od jego wartości potencjalnej wynikające $\mathrm{z}$ zaburzeń $\mathrm{w}$ funkcjonowaniu mechanizmu rynkowego oraz jego pewnych nieefektywności, które powinny być przedmiotem zainteresowania władz gospodarczych ${ }^{17}$.Jednakże doświadczenia niektórych krajów wysoko rozwiniętych w ostatnich dekadach uzmysławiają, że zmiany potencjalnego PKB wcale nie mają charakteru relatywnie łatwo estymowalnego trendu, a same cykliczne wahania mogą być efektem naturalnych zmian aktywności gospodarczej, które trudno jest uznać za konsekwencję nieefektywności mechanizmu rynkowego ${ }^{18}$.

\section{NIEEFEKTYWNOŚĆ INFORMACYJNA W WARUNKACH SZOKU PODAŻO- WEGO - PROBLEMY SZACOWANIA POTENCJALNEGO PKB}

Kwestia bieżącego, efektywnego szacowania poziomu potencjalnego PKB oraz problem precyzji dekompozycji PKB na wahania cykliczne aktywności gospodarczej i długookresowe przesunięcia trendu nabierają szczególnego znaczenia w warunkach średniookresowych dodatnich bądź ujemnych szoków podażowych oraz w warunkach długookresowych szoków technologicznych, prowadzących do zmian strukturalnych w gospodarce ${ }^{19}$. Przypadek niepowodzeń Stanów Zjednoczonych w zakresie polityki monetarnej w latach 70. XX wieku stanowi ważne studium przypadku pokazujące skalę wspomnianych problemów.

W literaturze można znaleźć co najmniej kilka koherentnych i przekonujących modelowych analiz wskazujących na źródła proinflacyjnych błędów amerykańskiej polityki monetarnej w tym czasie ${ }^{20}$. Jasne jest, że trudno jednoznacznie

${ }^{16}$ Zob. J. B. Taylor, Globalization and Monetary Policy: Missions Impossible, NBER Conference on the International Dimensions of Monetary Policy, Girona, Spain 2007, June 11-13; L. Ball, R. R. Tchaidze, The Fed and the Nerw Economy, „American Economic Review” 2002, vol. 92, no. 2, s. 108; J. Gali, The Conduct of Monetary Policy in the Face of Technological Change: Theory and Postwar U.S. Evidence, [w:] Stabilization and Monetary Policy: the International Experience, Banco de Mexico, Mexico City, Mexico 2000, 14-15 November; R. J. Hodrick, E. C. Prescott, Post War U.S. Business Cycles: An Empirical Investigation, „Journal of Money, Credit and Banking” 1997, vol. 29 , no. 1 , s. $1-16$.

${ }^{17}$ Federal Reserve Bank of Cleveland, Theory Ahead of Rhetoric: Measurement..., s. 9-10.

${ }^{18}$ Taka możliwość została sformułowana przez twórców szkoły realnego cyklu koniunkturalnego.

${ }^{19} \mathrm{OECD}$, The Implications of Supply-Side Uncertainties for Economic Policy, OECD Economic Outlook, 2008, vol. 83, s. 209-230.

${ }^{20}$ Obecnie dość powszechnie przyjmuje się, że inflacyjne obciążenie polityki monetarnej w latach 70. wynikało z dyskrecjonalnych, krótkowzrocznych oraz niespójnych działań władz monetarnych, które były sprzeczne ze współczesnymi pryncypiami dobrej polityki monetarnej. A. Orphanides, Monetary-Policy..., s. 115. 
wskazać najważniejsze powody sprawcze tych błędów ${ }^{21}$.Jednakże coraz więcej dowodów wskazuje na to, że szczególnie ważnym źródłem inflacyjnego obciążenia polityki monetarnej w latach 70 . był brak możliwości uwzględnienia w polityce monetarnej zmian strukturalnych zachodzących w gospodarce, które doprowadziły do ograniczenia o połowę długookresowego tempa wzrostu produktywności pracy, a tym samym istotnie wpływały na ograniczenie wysokości potencjalnego PKB. Wynikało to głównie $\mathrm{z}$ obciążeń bieżącej informacji dostępnej dla władz monetarnych ${ }^{22}$.

Jak już wspomniano w poprzednim paragrafie, kluczowym czynnikiem wpływającym na efektywność antycyklicznej polityki monetarnej jest zdolność do bieżącego oszacowania wielkości potencjalnego PKB, co jest tożsame z koniecznością trafnego oszacowania w czasie bieżącym nieobserwowalnych wartości naturalnej czy też neutralnej stopy procentowej oraz naturalnego poziomu bezrobo$\mathrm{cia}^{23}$. Standardowo takie analizy wykonywane są z zachowaniem dwóch założeń: a) o znanej, stabilnej lub przewidywalnej stopie NAIRU; b) o znanym, stabilnym lub przewidywalnym tempie wzrostu produktywności pracy ${ }^{24}$. W praktyce gospodarczej oba te założenia są dość trudne do spełnienia. Zarówno prognozowanie NAIRU, jak i w szczególności trafne przewidzenie zmiany trendu produktywności pracy stanowią jedno $\mathrm{z}$ największych wyzwań ekonomii stosowanej ${ }^{25}$.

${ }^{21}$ Według Allana Meltzera można mówić o dwóch głównych grupach przyczyn inflacji lat 70.: a) przyczyny związane $z$ procesem politycznym prowadzenia polityki gospodarczej, a więc zjawiskami opisywanymi na gruncie teorii politycznego cyklu koniunkturalnego i zjawiskiem braku spójności działań Rezerwy Federalnej związanej z ograniczoną jego niezależnością; b) bazowanie Rezerwy Federalnej na niewłaściwych teoriach i modelach. W ramach tej pierwszej grupy duże znaczenie miała zwyczajowa zasada dążenia do osiągnięcia konsensusu w ramach Komitetu Otwartego Rynku przed zmianami polityki gospodarczej, co skutkowało opóźnieniami przy podejmowaniu działań antyinflacyjnych. W ramach tej grupy przyczyn szczególne znaczenie miały reguły instytucjonalne narzucające konieczność koordynacji polityki fiskalnej oraz monetarnej, które jednocześnie ograniczały niezależność działań Rezerwy Federalnej. Ograniczało to możliwość prowadzenia szybkiej i efektywnej antyinflacyjnej polityki monetarnej. Według Allana Meltzera była to prawdopodobnie główna przyczyna „wielkiej inflacji” lat 70. W ramach drugiej grupy przyczyn odnoszących się do teorii niemal w całym okresie powojennym pracownicy oraz decydenci Rezerwy Federalnej ignorowali fundamentalną długookresową zależność pomiędzy wzrostem ilości pieniądza a inflacją. W rezultacie w latach 60 . i 70. dominowały poglądy o niemonetarnych źródłach inflacji. W związku z tym według większości analiz owego czasu inflacja stanowiła efekt przejściowych czynników, które nie wymuszały silnej odpowiedzi polityki gospodarczej. A. H. Meltzer, Origins of the Great Inflation, „Federal Reserve Bank of St. Louis Review” 2005, vol. 87, no. 2, part 2, s. 145-176.

${ }^{22}$ A. Orphanides, The Quest for Prosperity Without Inflation, European Central Bank Working Paper Series 2000, no. 15, March; A. Orphanides, S. van Norden, The Unreliability of Output Gap Estimates in Real Time, „Review of Economics and Statistics” 2002, vol. 84, no. 4, s. 569-583 .

${ }^{23}$ A. Orphanides, Monetary-Policy..., s. 116.

${ }^{24}$ Idem, The Quest for Prosperity..., s. 653-654.

${ }^{25}$ Szczególnie dużym wyzwaniem jest oszacowanie ex ante zmiany tempa wzrostu produk- 


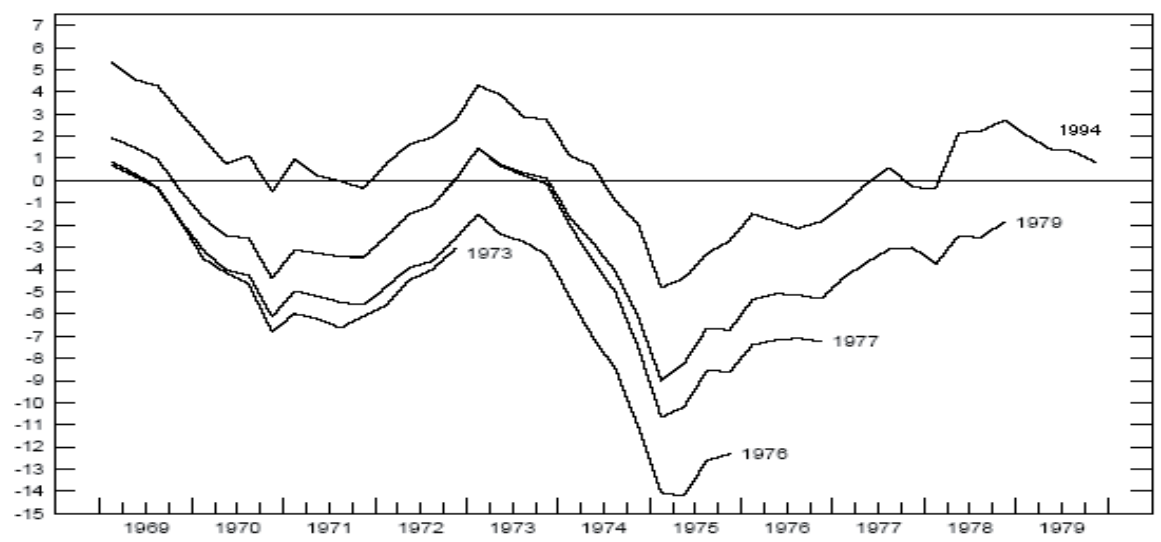

Wykres 1. Błędy w mierzeniu luki produktu (inflacyjnej luki oraz recesyjnej luki produktu) w latach $70 . \mathrm{XX}$ wieku w Stanach Zjednoczonych związane z zanieczyszczeniem bieżącej informacji

Źródło: A. Orphanides, The Quest for Prosperity Without Inflation, ,Journal of Monetary Economics" 2003, vol. 50, s. 665.

Zakres błędów, jakie mogą zostać popełnione w wypadku niespełnienia wspomnianych założeń, przedstawia wykres 1 zaczerpnięty z pracy A. Orphanidesa. Wykres ten ukazuje historyczne szacunki potencjalnego produktu bazującego na danych opublikowanych w Ekonomicznym Raporcie Prezydenta w latach 1973, 1976 oraz 1979, na podstawie których trudno było rozpoznać gwałtowne spowolnienie produktywności pracy. Wartości te zostały porównane z szacunkami potencjalnego produktu bazującego na danych dostępnych w 1994 roku, które nie były już obciążone bieżącymi informacyjnymi zanieczyszczeniami. Porównanie to pokazuje bardzo poważne błędy w zakresie mierzenia luki produktu w pierwszej połowie lat siedemdziesiątych, wiążące się z niespodziewanym spadkiem potencjalnego $\mathrm{PKB}$, który z swej natury może być rozpoznawalny stopniowo wraz $\mathrm{z}$ upływem czasu. Warto tu podkreślić, że już w połowie lat 70. rosła świadomość błędów w odniesieniu do szacunków potencjalnego PKB, w związku z czym rozpoczęto prace nad ich usunięciem. W 1977 roku dokonano znacznej korekty szacunków potencjalnego PKB. Po przeprowadzonej rewizji ocen stwierdzono, że realny PKB w 1976 roku był o cztery punkty procentowe bliżej do potencjal-

tywności pracy oraz rozdzielenie elementu cyklicznego od długookresowej zmiany, co pozwoliłoby na określenie trwałości tego zjawiska. Świadczyła o tym dyskusja wokół wpływu postępu technologicznego w branży IT i jego dyfuzji w całej gospodarce na produktywność pracy, tocząca się w Stanach Zjednoczonych w drugiej połowie lat 90. ubiegłego wieku. Potwierdza to także cały czas nierozstrzygnięta dyskusja wokół przyczyn spowolnienia tempa wzrostu produktywności w latach 70. Także bieżące analizy zmian NAIRU zazwyczaj charakteryzują się znaczącymi różnicami uwarunkowanymi podejściem metodologicznym, co zwiększa ryzyko popełnienia istotnego błędu. Kwestie te zostały syntetycznie omówione przez Laurence’a Balla i Roberta Tchaidze. L. Ball, R. Tchaidze, op. cit., s. 111-113. 
nego $\mathrm{PKB}$ w porównaniu $\mathrm{z}$ wcześniejszym stanem wiedzy ${ }^{26}$. Porównując jednak efekty tych prac $z$ kolejnych lat $z$ obecnie dostępnymi szacunkami pozbawionymi zanieczyszczeń informacyjnych (luka PKB szacowana na podstawie danych z 1994 r.), można stwierdzić, że mimo kolejnych rewizji szacunków (1977 oraz 1979) do końca lat 70. polityka gospodarcza była silnie obciążona błędami informacyjnymi.

Obecnie można stwierdzić, że uwzględniając dane makroekonomiczne dostępne dla decydentów monetarnych w czasie bieżącym, w latach 70. XX wieku w Stanach Zjednoczonych utrzymano politykę monetarną zgodną z celami stabilizacyjnymi zarówno w zakresie produktu, jak i inflacji, a mimo to wiązało się to $\mathrm{z}$ gwałtownym przyspieszeniem inflacji ${ }^{27}$. W tamtej sytuacji zbyt ekspansywna polityka monetarna wynikała $\mathrm{z}$ bieżącego przeszacowywania recesyjnego odchylenia się rzeczywistego PKB od jego wartości potencjalnej, co wiązało się z brakiem odróżnienia przejściowych zmian wynikających ze zmian produktywności od zmian o charakterze długookresowym ${ }^{28}$. W rezultacie obecnie panuje zgodność poglądów, iż najważniejszym źródłem tak dużych oraz długotrwałych błędów w zakresie szacunków potencjalnego $\mathrm{PKB}$, a tym samym luki produktu w latach 70. XX wieku, było szybkie podniesienie się NAIRU, a w szczególności spowolnienie tempa wzrostu produktywności pracy, które zaczęło się już w połowie lat 60. oraz gwałtownie przybrało na sile na przełomie lat 1973 i $1974^{29}$.

W przypadku inflacji lat 70. błędy prognoz oraz szacunków potencjalnego PKB przybrały szczególnie duże rozmiary oraz mogły wywierać szczególnie istotny wpływ na efektywność polityki monetarnej ze względu na szok podażowy prowadzący do przyspieszonej transformacji struktury gospodarczej. Jednakże A. Orphanides dowodzi w innym badaniu, że równie negatywne rezultaty dla efektywności acyklicznej polityki monetarnej mogą być wywołane w wyniku niewielkich systematycznych błędów w szacowaniu NAIRU oraz naturalnej stopy procentowej. W rezultacie szacunki neutralnej stopy procentowej oraz NAIRU, które są zbyt niskie, oraz zbyt optymistyczne prognozy inflacji lub zbyt pesy-

${ }^{26}$ A. Orphanides, The Quest for Prosperity..., s. 654-655.

27 Analizy symulacyjne przeprowadzone przez Athanasiosa Orphanidesa wykorzystujące współczesną informację oraz informację bieżącą dostępną władzom monetarnym w momencie podejmowania decyzji o restrykcyjności polityki monetarnej wskazują, że wbrew dominującym poglądom obciążenie inflacyjne w latach 70. nie wynikało $\mathrm{z}$ odstąpienia od zasad polityki stabilizacyjnej zgodnej z regułą Taylora, na co wskazywałyby symulacje bazujące na współczesnej nieobciążonej błędami informacji. Symulacje bazujące na informacji dostępnej decydentom monetarnym, która była jednak obciążona bieżącymi błędami w zakresie szacunków luki Okuna oraz inflacji, dowiodły, że inflacja przybrała takie rozmiary mimo prowadzenia polityki stabilizacyjnej zgodnej z rys. 1 i regułą Taylora. A. Orphanides, The Quest for Prosperity..., s. 648-649; idem, Monetary-Policy..., s. 115-120.

${ }^{28} \mathrm{~J}$. Gali, op. cit., s. 407-440.

${ }^{29}$ A. Orphanides, The Quest for Prosperity..., s. 656. 
mistyczne prognozy stopy bezrobocia mogą skutkować wskazaniami dla polityki monetarnej, która doprowadzi do rozbudzenia presji inflacyjnej ${ }^{30}$.

\section{NIEEFEKTYWNOŚĆ INFORMACYJNA W TZW. NORMALNYCH CZASACH - PROBLEMY SZACOWANIA POZIOMU BIEŻĄCEJ I PRZYSZŁEJ AKTYWNOŚCI GOSPODARCZEJ}

Oprócz problemu oszacowania poziomu potencjalnego PKB, jak wskazano szczególnie trudnego w warunkach szoków podażowych, należy także pamiętać, że efektywne oszacowanie luki produktu jest ściśle uzależnione od jakości bieżących danych dotyczących PKB lub poziomu bezrobocia, które są wykorzystywane do oceny aktualnego i przyszłego poziomu aktywności gospodarczej. Jak pokazuje praktyka, wczesne publikowane dane w tej materii są zazwyczaj z czasem istotnie korygowane. W konsekwencji wnioski z analiz opartych na bieżących danych, dotyczących rozmiarów luki produktu, często są obciążone dużym zakresem błędów, prowadząc do nieprawidłowych wskazań dla polityki monetarnej. Potwierdzają to badania OECD (tabela 1) wskazujące, że korekty danych pierwotnych nawet po kilku latach przekraczające pół punktu procentowego można traktować jako niemal standardowe zjawisko ${ }^{31}$.

Problemy ujemnych skutków informacyjnych związanych $z$ rewizją danych nabierają szczególnego znaczenia w odniesieniu do wskaźników aktywności gospodarczej ze względu na fakt, że dążąc do ograniczenia konsekwencji opóźnień czasowych, decydenci monetarni zmuszeni są do korzystania z prognoz wskaźników aktywności gospodarczej. Badania OECD dowodzą, że nawet w przypadku prognoz o relatywnie krótkim horyzoncie czasowym pojawiają się istotne zanieczyszczenia informacyjne, natomiast jednoroczne prognozy stanu aktywności gospodarczej dostarczają już niemal zawsze informacji o wątpliwej jakości decyzyjnej ${ }^{32}$. Jak wynika $\mathrm{z}$ wykresu 2, prognozy dotyczące stanu gospodarki w roku

${ }^{30} \mathrm{~W}$ badaniu tym Athanasiosa Orphanides przyjął funkcję reakcji opartej na regule Taylora i uwzględniającej oczekiwania w następującym kształcie: $f=r^{*}+\Pi^{*}+\beta\left(\Pi-\Pi^{*}\right)+\gamma\left(u^{*}-u\right)$, gdzie $\mathrm{u}^{*}$ - stanowi NAIRU, $\Pi^{*}$ stanowi docelową stopę inflacji, $\mathrm{f}$ stanowi federalną stopę procentową, $\mathrm{r}^{*}$ stanowi neutralną stopę procentową, u stanowi prognozę stopy bezrobocia, a $\Pi$ prognozę dla stopy inflacji. Przyjmując zgodnie $z$ tradycyjną regułą Taylora oraz powszechnie akceptowalnymi szacunkami $\beta=\gamma=1,5$ oraz $\Pi^{*}=r^{*}=2$, prognozy inflacji oraz szacunki NAIRU, które są systematycznie zbyt niskie o 1 punkt procentowy, prowadzą do polityki monetarnej obarczonej zniekształconym celem inflacyjnym, który jest o 3 punkty procentowe za wysoki. Błędy te są jeszcze wyższe w wypadku wystąpienia wyższego $\gamma$ lub niższego $\beta$. A. Orphanides, Monetary-Policy..., s. 117.

${ }^{31}$ OECD, op. cit., s. 217.

32 Ibidem, s. 217-218. 
bieżącym są istotnie skorelowane $\mathrm{z}$ ostatecznymi skorygowanymi danymi, mogą być więc traktowane jako akceptowalne źródło informacji. Jednakże prognozy formułowane $\mathrm{z}$ jednorocznym wyprzedzeniem są już źródłem informacji bardzo niskiej jakości, której wykorzystanie może prowadzić do błędnych wskazań dla siły, a nawet kierunku określonych działań monetarnych.

Tabela 1. Średnie różnice pomiędzy pierwotnymi publikowanymi danymi a danymi skorygowanymi

\begin{tabular}{|l|c|c|c|}
\hline \multicolumn{1}{|c|}{ KrAJ } & LUKA PRODUKTU & RZECZYWISTY PKP & PotenCJALNY PKB $^{*}$ \\
\hline USA & 0,46 & 0,61 & 0,43 \\
\hline Japonia & 1,09 & 0,82 & 0,35 \\
\hline Strefa euro & 0,26 & 0,20 & 0,14 \\
\hline Niemcy & 0,41 & 0,43 & 0,35 \\
\hline Francja & 0,36 & 0,35 & 0,15 \\
\hline Włochy & 0,35 & 0,22 & 0,34 \\
\hline Wielka Brytania & 0,38 & 0,42 & 0,22 \\
\hline Kanada & 0,37 & 0,50 & 0,26 \\
\hline
\end{tabular}

Dla wszystkich krajów z wyjątkiem strefy euro próba badawcza dotyczyła lat 1994-2003, dla krajów strefy euro były to lata 1997-2003. Tabela pokazuje różnice pomiędzy danymi opublikowanymi w okresie $t+1$ a danymi skorygowanymi w okresie $t+4$ dla danych publikowanych w OECD Economic Outlook.

* Wyrażone jako różnica log.

Źródło: OECD, The Implications of Supply-Side Uncertainties for Economic Policy " „OECD Economic Outlook" 2008, vol. 83, s. 217.

Zdiagnozowany problem przekłada się na fundamentalną dla polityki monetarnej kwestię prognozowania procesów inflacyjnych. Niepewność dotycząca prognoz aktywności gospodarczej zwiększa zakres niepewności dotyczącej prognoz inflacji, co naturalnie komplikuje proces kształtowania polityki monetarnej oraz może ograniczać jej efektywność. Kwestia ta została przedstawiona na wykresie 3. Banki centralne ograniczają problem negatywnego wpływu prognozowanych zmiennych egzogenicznych na projekcje inflacji w wyniku stosowania szerokiego spektrum zmiennych diagnostycznych służących opisowi presji inflacyjnej oraz uwzględniając $\mathrm{w}$ procesie programowania polityki monetarnej wartość przyszłego potencjalnego PKB. Jednak - jak już wykazano w przypadku błędu prognozy dotyczącego np. spadku potencjalnego PKB - bardzo prawdopodobne jest niedoszacowanie przez bank centralny obecnej oraz przyszłej presji inflacyjnej, prowadzące do nadmiernego rozluźnienia polityki monetarnej ${ }^{33}$. Problem ten staje się szczególnie groźny w warunkach tzw. spłaszczenia NAIRU oraz ograniczenia

${ }^{33}$ Ibidem, s. 219. 
związków pomiędzy rozmiarami krajowej luki popytowej a inflacją, które w sposób znaczący podnoszą koszty związane z proinflacyjnymi błędami polityki monetarnej ${ }^{34}$.

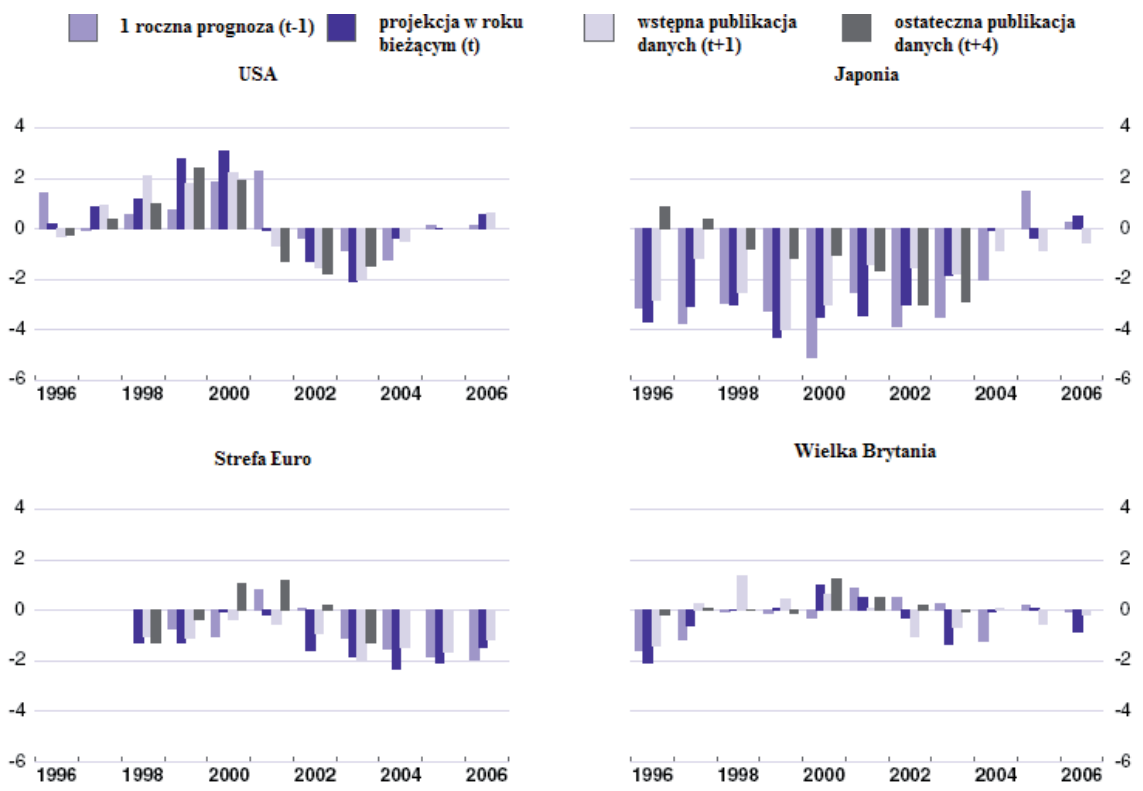

Wykres 2. Luka produktu - kolejne rewizje danych oraz prognozy

Źródło: OECD, The Implications of Supply-Side Uncertainties for Economic Policy „ "OECD Economic Outlook” 2008, vol. 83, s. 218.

Podsumowując niniejsze rozważania, warto przytoczyć opinię A. Orphanidesa, według którego dla pełnego uniknięcia omówionych błędów i problemów diagnostycznych w zakresie oceny wpływu notowanych szoków podażowych na potencjalny $\mathrm{PKB}$ oraz problemu oceny bieżącego stanu gospodarki, jak również zminimalizowania ich ewentualnych negatywnych konsekwencji, nie wystarczy tylko poprawienie metodologii mierzenia NAIRU i zmian produktywności pracy, czy też poprawienie jakości statystyk, ale wymagałoby to uzyskania pełnej wiedzy o czynnikach wpływających na tzw. resztę Solowa z jego neoklasycznego modelu egzogenicznego wzrostu gospodarczego. Zadanie to wydaje się jednak trudne do zrealizowania $^{35}$. W świetle przeprowadzonej analizy sceptycyzm ten nie wyda-

${ }^{34}$ Problem spłaszczenia NAIRU oraz konsekwencji tego zjawiska dla polityki monetarnej został omówiony w pracy: A. P. Balcerzak, Monetary policy under conditions of NAIRU "flattening", „Olsztyn Economic Journal” 2009, nr 4 (1), s. 95-105.

${ }^{35}$ A. Orphanides, The Quest for Prosperity..., s. 656. 
je się przesadzony. W obliczu obecnie obserwowanej powszechnej transformacji światowego sytemu gospodarczego, szczególnie w kontekście rosnącego usieciowienia gospodarki o charakterze globalnym, wzrostu ekonomicznego znaczenia jakości nienamacalnych czynników organizacyjnych oraz instytucji, jak również wzrostu turbulentności procesów gospodarczych ${ }^{36}$, można oczekiwać, że powyższe problemy nabierają coraz większego znaczenia.

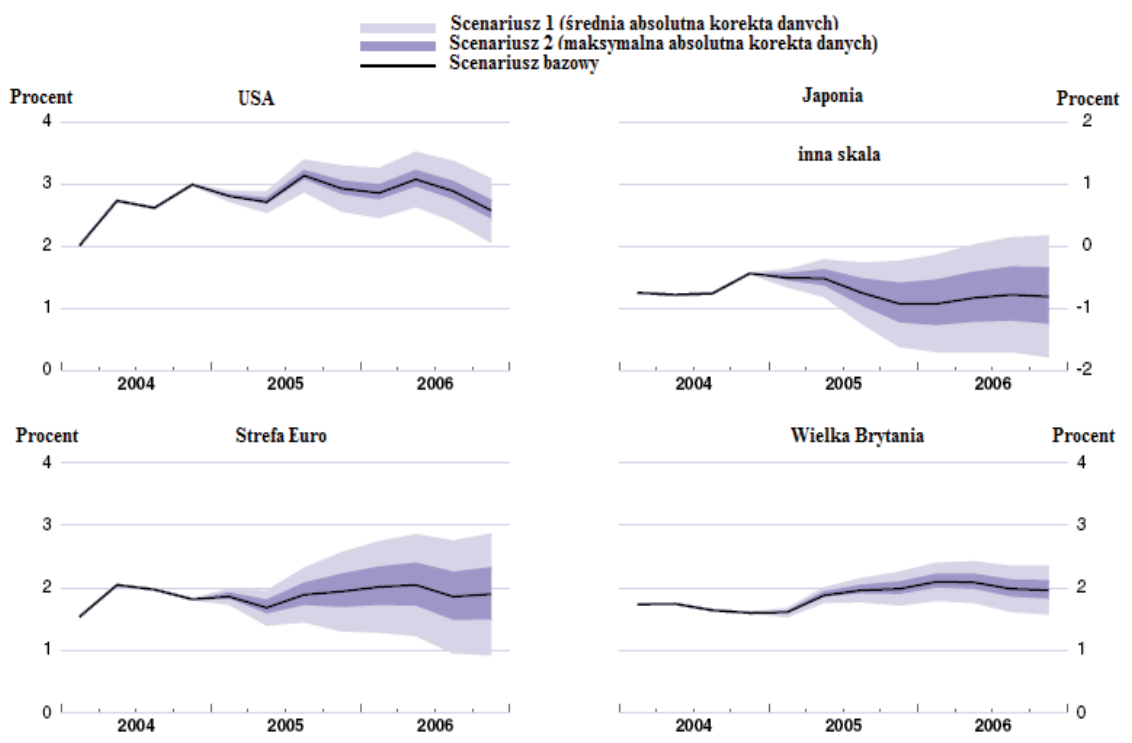

Wykres 3. Konsekwencje niepewności dotyczącej szacunków luki produktu dla prognozowania procesów inflacyjnych

W przypadku scenariusza bazowego estymowano CPI z wykorzystaniem modelu krzywej Phillipsa do końca 2004 r.t do końca 2006 r. została wygenerowana dynamiczna prognoza inflacji wykorzystująca rzeczywiste dane dla wszystkich zmiennych egzogenicznych. Następnie oszacowano dwa alternatywne scenariusze. W przypadku pierwszego rozmiary luki produktu dla każdej gospodarki zostały skorygowane o średnią absolutną korektę zaobserwowaną w latach 1995-2006 pomiędzy projekcją z danego roku a ostatecznym wynikiem w okresie t +4 . W przypadku drugiego scenariusza luka produktu została skorygowana o maksymalną absolutną rewizję dla wspomnianego okresu. Prognozy dotyczące strefy euro zostały otrzymane jako średnia ważona prognoz dla Niemiec, Francji i Włoch z uwzględnieniem wag konsumpcji dla roku 2005.

Źródło: OECD, The Implications of Supply-Side Uncertainties for Economic Policy, „OECD Economic Outlook” 2008, vol. 83, s. 220.

${ }^{36}$ Zob. A. P. Balcerzak, Państwo a wyzwania nowej globalnej gospodarki XXI wieku, [w:] A. P. Balcerzak, E. Rogalska (red.), Europa wobec wyzwań gospodarki globalnej, Wydawnictwo Adam Marszałek, Toruń 2008; A. P. Balcerzak, Sieciowa logika gospodarki globalnej jako wyzwanie dla wspótczesnego przedsiębiorstwa, I Ogólnopolska Konferencja pt. Przedsiębiorstwo w otoczeniu globalnym, Wydział Ekonomiczny, Uniwersytet Gdański, Sopot 23-24 października 2008. 


\section{ZAKOŃCZENIE}

W ostatnich latach w literaturze przedmiotu coraz częściej można spotkać się z opiniami, według których nowocześnie prowadzona polityka monetarna daje gwarancje nie tylko zapewnienia wysokiej stabilności pieniądza, co jest explicite wyrażanym celem każdego banku centralnego, ale stanowi także coraz bardziej efektywne narzędzie stabilizacji aktywności gospodarczej w sferze realnej. Gwarancją tego są wysoka niezależność i banków centralnych oraz stosowanie reguł polityki monetarnej, które z jednej strony zapewniają dyscyplinę eliminującą negatywne konsekwencje niespójności w czasie, a z drugiej - dzięki wystarczającej elastyczności i uwzględnianiu prognoz oraz oczekiwań przyszłego stanu aktywności gospodarczej rozwiązują problemy związane z opóźnieniami mechanizmów transmisji monetarnej.

Przeprowadzana analiza dowodzi jednak, że pomimo ogromnych postępów w zakresie teorii oraz błyskawicznego rozwoju narzędzi statystycznych i ekonometrycznych, podnoszących zdolności banków centralnych do diagnozowania i prognozowania stanu aktywności gospodarczej, ważnym zagrożeniem dla efektywności monetarnej polityki stabilizacyjnej jest cały czas problem nieefektywności informacyjnej decydenta gospodarczego. Podejmując decyzję o kształcie polityki monetarnej generującej realne bodźce gospodarcze, skutkujące z kilkumiesięcznym opóźnieniem, decydent gospodarczy musi posługiwać się bieżącymi danymi o różnym stopniu zanieczyszczenia informacyjnego. Oznacza to, że banki centralne, decydując o działaniach, których celem jest nie tylko ochrona siły nabywczej pieniądza, ale także działania o charakterze antycyklicznym, powinny cały czas zachowywać bardzo daleko posuniętą ostrożność.

\section{THE INFLUENCE OF INFORMATION FAILURE OF THE MONETARY AUTHORITIES ON THE EFFECTIVENESS OF COUNTER-CYCLICAL STABILIZATION POLICY \\ SUMMARY}

With the huge advances in the field of theoretical and applied econometrics recent years have made a period of growing faith in the analytical and forecasting abilities of economists, which have resulted in a growing belief in the increasing ease of conducting counter-cyclical monetary policy and its high effectiveness. However, the thesis of this article says that the information ineffectiveness of monetary authorities related to uncertainty concerning correctness of current data, which is the basis for shaping the strength and direction of monetary action, may jeopardize the effectiveness of counter-cyclical stabilization policy. This problem is particularly important in the context of estimating the output gap between the actual and potential product. Despite the increasing quality of data and rapid advances in econometrics and the theory of monetary policy this problem is still valid. 